\title{
SMALL TIME SCALE PLANKTON STRUCTURE VARIATIONS AT THE ENTRANCE OF A TROPICAL EUTROPHIC BAY (GUANABARA BAY, BRAZIL)
}

\author{
Mariana Guenther ${ }^{1,3^{*}}$, Isabel Lima ${ }^{l}$, Glenda Mugrabe ${ }^{l}$, Denise Rivera Tenenbaum ${ }^{l}$, \\ Eliane Gonzalez-Rodriguez ${ }^{2}$ and Jean Louis Valentin ${ }^{1}$ \\ ${ }^{1}$ Universidade Federal do Rio de Janeiro - Departamento de Biologia Marinha, Instituto de Biologia \\ (21949-900 Rio de Janeiro, RJ, Brasil) \\ ${ }^{2}$ Instituto de Estudos do Mar Almirante Paulo Moreira - Departamento de Oceanografia \\ (28930-000 Arraial do Cabo, RJ, Brasil) \\ ${ }^{3}$ Present Address: Universidade de Pernambuco - Instituto de Ciências Biológicas \\ (50100-130 Recife, PE, Brasil) \\ *Corresponding author: mariguenther@gmail.com
}

\begin{abstract}
A B S TRACT
The dynamics of the plankton compartments at the entrance of Guanabara Bay (SE Brazil) were assessed during a short-term temporal survey to estimate their trophic correlations. Size-fractioned phytoplankton (picoplankton: $<2 \mu \mathrm{m}$, nanoplankton: 2-20 $\mu \mathrm{m}$ and microplankton: $>20 \mu \mathrm{m}$ ) biomass and photosynthetic efficiency, composition and abundance of the auto- and heterotrophic nano- and microplankton, and mesozooplankton were evaluated at a fixed station for 3 consecutive days at 3-h intervals, in the surface and bottom $(20 \mathrm{~m})$ layers. The variability of almost all plankton compartments in the surface layer was directly dependent on temperature, indicating the great influence of the circulation at the entrance of the bay on plankton structure. In the surface layer, the mesozooplankton seems to be sustained by both autotrophic nano- and picoplankton, this last being channeled through the microzooplankton. Near the bottom, both auto- and heterotrophic microplankton are probably supporting the mesozooplankton biomass. Our findings thus suggest that the entrance of Guanabara bay presents a multivorous food web, i.e., a combination of both grazing and microbial trophic pathways.
\end{abstract}

\section{RESUMO}

A dinâmica dos vários compartimentos do plâncton foi avaliada durante uma série de curta duração na entrada da baía de Guanabara (SE do Brasil), com o objetivo de estimar suas correlações tróficas. A biomassa e eficiência fotossíntética das três frações do fitoplâncton (picoplâncton: $<2 \mu \mathrm{m}$, nanoplâncton: $2-20 \mu \mathrm{m}$ e microplâncton: > $20 \mu \mathrm{m}$ ), juntamente com a composição e abundância do nano- e microplâncton auto- e heterótrofos e do mesozooplâncton, foram determinadas em uma estação fixa durante 3 dias consecutivos, a intervalos de $3 \mathrm{~h}$, nas camadas de superfície e de fundo $(20 \mathrm{~m})$. A variabilidade de quase todos os compartimentos do plâncton na superfície foi diretamente relacionada à temperatura, indicando forte influência da circulação da entrada da baía na estrutura planctônica. Na camada superficial, o mesozooplâncton parece ser alimentado pelo nano- e picoplâncton autótrofos, esse último sendo sustentado pelo microzooplâncton. Próximo ao fundo, o microplâncton auto- e heterótrofo estão possivelmente sustentando a biomassa mesozooplanctônica. Nossos resultados sugerem, portanto, que na entrada da baía de Guanabara esteja estabelecida uma rede trófica multívora, i.e., uma combinação entre as cadeias microbiana e de pastagem.

Descriptors: Phytoplankton, Microzooplankton, Mesozooplankton, Grazing food web, Microbial food web, Carbon fluxes.

Descritores: Fitoplâncton, Microzooplâncton, Mesozooplâncton, Rede trófica de pastagem, Rede trófica microbiana, Fluxos de carbono.

\section{INTRODUCTION}

The comprehension of the plankton community structure of a system is crucial for predicting the carbon fluxes within its food webs and determining its export processes (e.g. TIAN et al., 2000; RIVKIN; LEGENDRE, 2002; CALBET; LANDRY, 2004; VARGAS et al., 2007; STUKEL et al., 2011).
Generally, the plankton trophic structure of temporally steady aquatic systems, such as lakes and open oceans, is usually related to the water column stability and nutritional profile: in more eutrophic and turbulent systems, larger phytoplankton cells prevail, leading to the establishment of the shorter classical (or grazing) food web, while in more oligotrophic and stratified systems the smaller producers dominate the plankton, 
and the longer microbial food web prevails (LEGENDRE; LE FEVRE, 1995; LEGENDRE; RASSOULZADEGAN, 1996).

In estuaries and coastal bays, the lateral transport and pulses of nutrients and organisms from both terrestrial and oceanic sides result in a hydrodynamic complexity such that the short term variations in chemical and physical parameters like temperature, salinity, nutrient and organic matter contents and tidal currents have an important impact on the biotic interactions (DYER, 1997; MIRANDA et al., 2002). It is thus to be expected that the trophic relationships within the plankton in these systems will be more complex than those stated for steadier ones.

Guanabara Bay $\left(22^{\circ} 41^{\prime}-22^{\circ} 56^{\prime} \mathrm{S}\right.$; $43^{\circ} 02^{\prime}$ $43^{\circ} 18^{\prime} \mathrm{W}$ ) has a tropical humid climate (Aw) with dry cool winters and wet warm summers (KÖPPEN, 1900). This system presents a wide spatial eutrophication gradient, increasing from the entrance to the inner bay (MAYR et al., 1989). This variation is due to the balance between terrestrial influence, i.e., inputs of high loads of nutrients and organic material from riverine sources and from domestic and industrial sewage, and oceanic forces, i.e., strong tidal currents $\left(80-150 \mathrm{~cm} \mathrm{~s}^{-1}\right)$ at the narrow entrance of the bay (JICA, 1994). The plankton communities of Guanabara Bay have been well studied since the beginning of the XXth century on both short and long term scales, providing a relevant array of information about the dynamics of the autotrophic microplankton (VILLAC; TENENBAUM, 2010 and references therein), bacterioplankton (GUENTHER et al., 2008b), auto- and heterotrophic nanoplankton (SANTOS et al., 2007), microzooplankton (GOMES et al., 2007) and mesozooplankton (e.g. WANDERNESS et al., 1997; VALENTIN et al., 1999; GOMES et al., 2004; SCHWAMBORN et al., 2004). Nevertheless, none of them has yet evaluated the dynamics of the auto- and heterotrophic plankton compartments simultaneously.

The present study was undertaken at the entrance of Guanabara Bay during the summer (= wet season) over a short time scale, covering the end of the spring tide and the beginning of the neap tide. The variability of the physical and chemical conditions of this site and period, discussed in greater detail in a previous paper (GUENTHER et al., 2008b), indicates a highly hydrological complexity. During the spring tide, there was great water-column mixing with high homogeneity of temperature, salinity and nutrients over depth. However, at the neap tide, the high watercolumn stability suggested the establishment of gravitational circulation, with outflow at the surface and inflow near the bottom. This pattern was also corroborated by the increase in temperature and decrease in salinity at the surface, indicating the influence of the inner bay waters, and the decrease in temperature and increase in $\mathrm{N}-\mathrm{NO}_{3}$ concentrations near the bottom, demonstrating the influence of the coastal ocean.

In this paper, the composition and abundance of the autotrophic pico-, nano- and microplankton, heterotrophic nanoplankton, microzooplankton and mesozooplankton are correlated with some important physical and chemical parameters in order to understand how the plankton are structured in this hydrologically complex system.

\section{Material and Methods}

The samplings were performed at a fixed station (22 $54^{\prime} \mathrm{S} ; 4^{\circ} 09^{\prime} \mathrm{W}$, Fig. 1) at $3 \mathrm{~h}$ intervals during 3 consecutive days - February 9 to 12, 2004 (Fig. 1). The water samples were collected with Niskin bottles $(10 \mathrm{~L})$ at the surface and near the bottom $(20$ $\mathrm{m})$, aboard the RV 'Astrogaroupa' (Petrobras) and immediately processed or stored.

Phytoplankton biomass (PB) was estimated as size-fractionated chlorophyll $a$ contents. The 150 $\mathrm{mL}$ water samples were successively filtered through $20 \mu \mathrm{m}$ net (microplankton), $2.0 \mu \mathrm{m}$ polycarbonate membranes (nanoplankton) and $0.45 \mu \mathrm{m}$ cellulose membranes (picoplankton)and chl $a$ concentrations were determined after $18 \mathrm{~h}$ acetone $90 \%$ extraction at $4^{\circ} \mathrm{C}$ in accordance with Parsons et al. (1984). Phytoplankton photosynthetic efficiency $\left(\mathrm{P}^{\mathrm{B}}\right)$ was estimated as the ratio between primary production (PP) and chl $a(\mathrm{~PB})$ for all size classes. Size-fractioned $\mathrm{PP}$ was determined in accordance with SteemannNielsen (1952). The $75 \mathrm{~mL}$ water samples were incubated in situ with $10 \mu \mathrm{Ci} \mathrm{NaH}{ }^{14} \mathrm{CO}_{3}$ for $3 \mathrm{~h}$ and immediately filtered through a $20 \mu \mathrm{m}$ net, $2.0 \mu \mathrm{m}$ polycarbonate and $0.45 \mu \mathrm{m}$ cellulose membranes. Irradiance profiles were obtained at each sampling using a Seabird Seacat 19 CTD system.

Nanoplankton and microplankton samples were preserved alive and in $2 \%$ buffered paraformaldehyde, both stored at $5^{\circ} \mathrm{C}$ on board (SHERR, E.B.; SHERR, B. F., 1993). Individual identification and enumeration were performed through the settling technique (UTERMÖHL, 1958) under an inverted optical microscope with a combination of epifluorescence under blue and green light excitation and bright field. The trophic status (auto- or heterotrophic) of the nano- and microplankton species was determined through both fluorescence on live samples and literature data.

Mesozooplankton samples were obtained through $20 \mathrm{~m}$ vertical hauling with a conical, $200 \mu \mathrm{m}$ mesh net and preserved in $4 \%$ buffered paraformaldehyde on board (GRIFFTHS et al., 1976). Individual identification and enumeration were performed under optical and stereoscopic microscopes, based on BOLTOVSKOY (1999). 


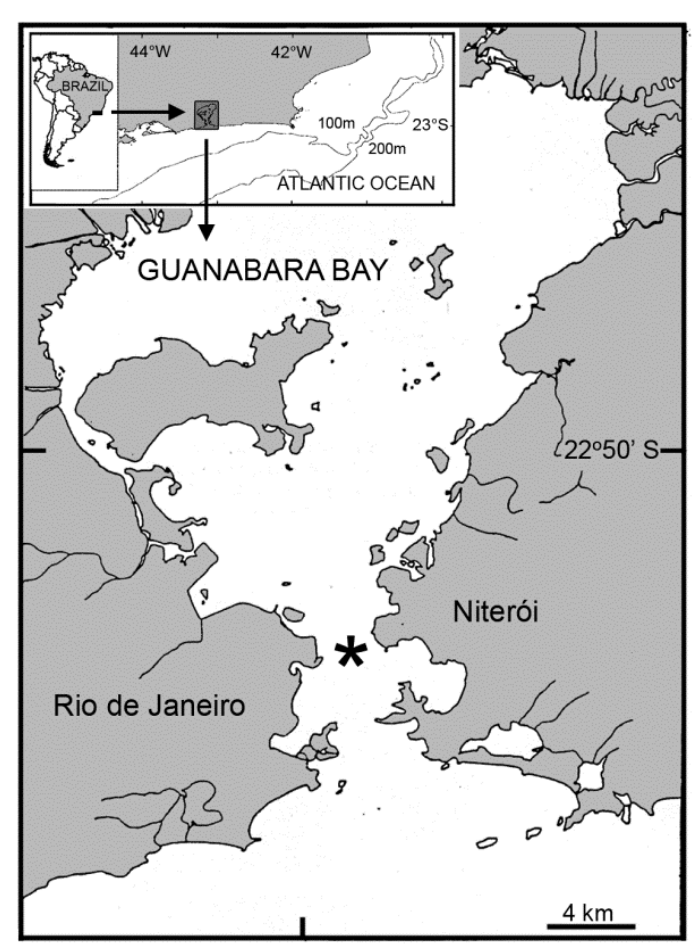

Fig. 1. Study area and fixed sampling station.

The abiotic conditions of the present study have been presented and discussed in greater detail in a previous paper (GUENTHER et al., 2008b). They include temperature, salinity and density profiles, dissolved oxygen (DO), nutrients $\left(\mathrm{NH}_{4}{ }^{+}, \mathrm{NO}_{2}^{-}, \mathrm{NO}_{3}{ }^{-}\right.$, $\mathrm{PO}_{4}{ }^{3+}$ and $\mathrm{SiO}_{4}{ }^{-}$) and dissolved organic carbon (DOC) contents. All these abiotic parameters were determined on the same samples described above.

Differences between layers for each measured variable were verified using a MannWhitney U-test. Differences between some variables at each layer were verified using a Mann-Whitney Utest (for two variables) or a Kruskal-Wallis ANOVA test (for more than two variables). The relationships between plankton compartments and some selected predictor variables were analyzed through standard (including intercept) forward-stepwise multiple regression. The models were executed with a tolerance $>0.10$ and residual statistics were computed in order to identify any extreme outliers. When one or several cases fell outside \pm 3 times the residual limit's standard deviation, the respective cases were excluded and the analysis repeated. The predictor variables included the abundance or biomass of the plankton compartments measured in the present study and some physical and chemical variables (temperature, $\mathrm{NH}_{4}{ }^{+}$ contents and DOC contents) described in Guenther et al. (2008b). The models were executed for both layers separately. For the mesozooplankton data, which were integrated for the whole water column, the same data were used for both surface and bottom models. All tests were performed using Statistica version 7.0.

\section{RESULTS}

\section{Phytoplankton Biomass}

The autotrophic nanoplankton was the dominant size class at the surface ( $80 \%$ of total PB), followed by microplankton (18\%) and picoplankton $(2 \%)$ (K-W: p < 0.0001). Near the bottom, both nanoplankton $(54 \%)$ and microplankton biomass $(44 \%)$ were equivalent and higher than that of picoplankton $(2 \%)(\mathrm{K}-\mathrm{W}: \mathrm{p}<0.0001)$. (Table 1 and Figs. 2a,b).

The multiple regression models showed that the variation in $\mathrm{PB}_{\text {micro }}$ at the surface $\left(\mathrm{R}^{2}=0.39\right)$ was directly dependent on temperature $(\beta=0.53)$, and near the bottom $\left(\mathrm{R}^{2}=0.36\right)$ it was directly dependent on mesozooplankton abundance (MeZA) $(\beta=0.66)$. The variation in $\mathrm{PB}_{\text {nano }}$ at the surface $\left(\mathrm{R}^{2}=0.67\right)$ was also directly dependent on MeZA $(\beta=0.70)$ and inversely dependent on $\mathrm{N}-\mathrm{NH}_{4}(\beta=-0.66)$, and near the bottom $\left(\mathrm{R}^{2}=0.35\right)$ it was directly dependent on $\mathrm{N}-\mathrm{NH}_{4}(\beta=$ $0.45)$. The variation in $\mathrm{PB}_{\text {pico }}$ at the surface $\left(\mathrm{R}^{2}=0.65\right)$ was directly dependent on temperature $(\beta=0.64)$ and microzooplankton abundance (MiZA) $(\beta=0.32)$, but none of the selected variables explained $\mathrm{PB}_{\text {pico }}$ variation near the bottom (Table 2).

Table 1. Mean values and standard deviations (in parentheses) of size-fractioned phytoplankton biomass (PB) and photosynthetic efficiency $\left(\mathrm{P}^{\mathrm{B}}\right)$ and microzooplankton abundance (MiZA) at both layers.

\begin{tabular}{lcc}
\hline \hline Layer & Surface & $20 \mathrm{~m}$ \\
\hline $\mathrm{PB}_{\text {pico }}\left(\mu \mathrm{g} \operatorname{chl} a \mathrm{~L}^{-1}\right)$ & $0.64(0.64)$ & $0.08(0.03)$ \\
$\mathrm{PB}_{\text {nano }}\left(\mu \mathrm{g} \operatorname{chl} a \mathrm{~L}^{-1}\right)$ & $31.0(20.6)$ & $2.64(0.82)$ \\
$\mathrm{PB}_{\text {micro }}\left(\mu \mathrm{g} \operatorname{chl} a \mathrm{~L}^{-1}\right)$ & $7.73(9.37)$ & $2.14(0.61)$ \\
$\mathrm{P}_{\text {pico }}^{\mathrm{B}}\left(\mu \mathrm{g} \mathrm{C} \mu \mathrm{g} \mathrm{chl} a^{-1} \mathrm{~h}^{-1}\right)$ & $6.64(4.64)$ & $2.37(2.86)$ \\
$\mathrm{P}_{\text {nano }}^{\mathrm{B}}\left(\mu \mathrm{g} \mathrm{C} \mu \mathrm{g} \mathrm{chl} a^{-1} \mathrm{~h}^{-1}\right)$ & $6.34(4.35)$ & $0.14(0.17)$ \\
$\mathrm{P}_{\text {micro }}^{\mathrm{B}}\left(\mu \mathrm{g} \mathrm{C} \mu \mathrm{g} \mathrm{chl} a^{-1} \mathrm{~h}^{-1}\right)$ & $1.31(1.71)$ & $1.22(1.17)$ \\
$\mathrm{MiZA}\left(10^{6} \mathrm{ind} \mathrm{L} \mathrm{L}^{-1}\right)$ & $0.06(0.10)$ & $0.01(0.01)$ \\
\hline
\end{tabular}



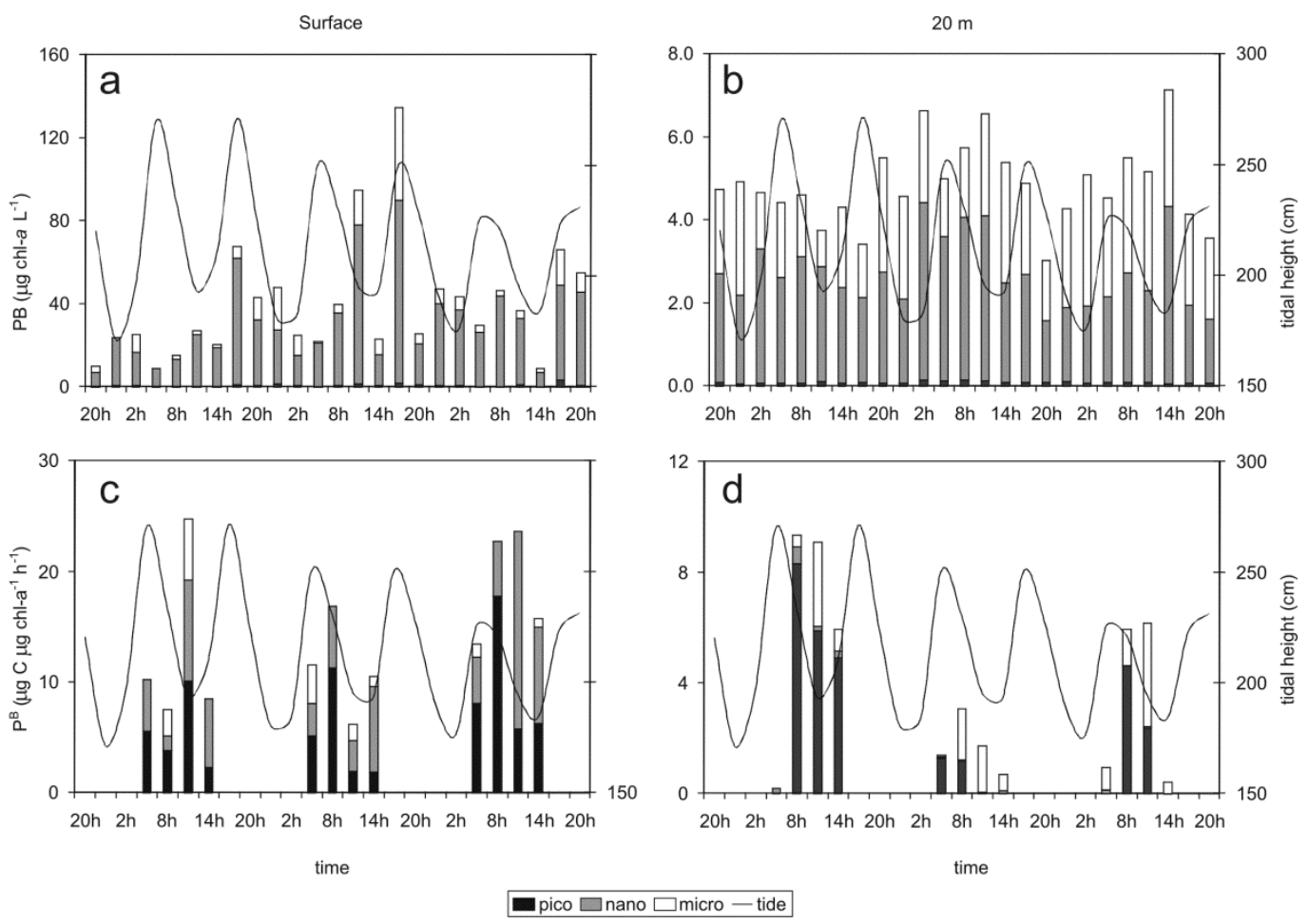

Fig. 2. Phytoplankton biomass (a,b) and photosynthetic efficiency $(\mathrm{c}, \mathrm{d})$ of the three size classes at the surface and $20 \mathrm{~m}$. Lines indicate tidal height.

Table 2. Multiple regression models: $R^{2}, \beta$ and partial $r$ values (in parentheses below $\beta$ values) for the plankton compartments variations with selected variables: temperature $(\mathrm{T}), \mathrm{NH}_{4}$ contents, $\mathrm{DOC}$ contents (from Guenther et al., 2008b), autotrophic biomass of picoplankton ( $\left.\mathrm{PB}_{\text {pico }}\right)$ nanoplankton $\left(\mathrm{PB}_{\text {nano }}\right)$ and microplankton $\left(\mathrm{PB}_{\text {micro }}\right)$, microzooplankton and mesozooplankton abundances (MiZA and MeZA). Single (*), double (**) and triple (***) asterisks mean significant differences at $p<0.05, p<0.01$, and $p<0.001$, respectively. The code " $x$ " indicates that the variable was not included in the model.

\begin{tabular}{|c|c|c|c|c|c|c|c|c|c|c|}
\hline \multirow{2}{*}{$\begin{array}{l}\text { Layer } \\
\text { Compartments }\end{array}$} & \multicolumn{5}{|c|}{ Surface } & \multicolumn{5}{|c|}{$20 \mathrm{~m}$} \\
\hline & $\mathrm{PB}_{\text {micro }}$ & $\mathrm{PB}_{\text {nano }}$ & $\mathrm{PB}_{\text {pico }}$ & MiZA & $\mathrm{MeZA}^{\dagger}$ & $\mathrm{PB}_{\text {micro }}$ & $\mathrm{PB}_{\text {nano }}$ & $\mathrm{PB}_{\text {pico }}$ & MiZA & $\mathrm{MeZA}^{\dagger}$ \\
\hline $\mathrm{R}^{2}$ & $0.39^{* *}$ & $0.67^{* * * *}$ & $0.65^{\text {**** }}$ & $0.93^{* * *}$ & $0.73^{* * *}$ & $0.36^{*}$ & 0.35 & 0.38 & 0.50 & $0.93^{\text {**** }}$ \\
\hline$\beta_{(\mathrm{N}-\mathrm{NH} 4)}$ & & $\begin{array}{l}-0.66^{* *} \\
(-0.65)\end{array}$ & & & $\begin{array}{l}0.50^{\text {**** }} \\
(0.66)\end{array}$ & & $\begin{array}{l}0.45^{*} \\
(0.46)\end{array}$ & & & \\
\hline$\beta_{(\mathrm{DOC})}$ & & & & & & & & & & $\begin{array}{l}-0.23^{*} \\
(-0.56)\end{array}$ \\
\hline$\beta_{(\mathrm{T})}$ & $\begin{array}{l}0.53^{* *} \\
(0.56)\end{array}$ & & $\begin{array}{l}0.64^{\text {**** }} \\
(0.70)\end{array}$ & $\begin{array}{l}0.42^{*} \\
(0.54)\end{array}$ & $\begin{array}{l}0.47^{* *} \\
(0.57)\end{array}$ & & & & & $\begin{array}{l}-0.35^{* *} \\
(-0.71)\end{array}$ \\
\hline$\beta_{\text {(PBmicro) }}$ & $\mathrm{x}$ & $\mathrm{x}$ & $\mathrm{x}$ & $\begin{array}{l}-0.38^{* *} \\
(-0.63)\end{array}$ & & $\mathrm{x}$ & $\mathrm{x}$ & $\mathrm{x}$ & & \\
\hline$\beta_{\text {(PBnano) }}$ & $\mathrm{x}$ & $\mathrm{x}$ & $\mathrm{x}$ & $\begin{array}{l}-0.36^{* *} \\
(-0.63)\end{array}$ & & $\mathrm{x}$ & $\mathrm{x}$ & $\mathrm{x}$ & & \\
\hline$\beta_{\text {(PBpico) }}$ & $\mathrm{x}$ & $\mathrm{x}$ & $\mathrm{x}$ & $\begin{array}{l}1.02^{* * *} \\
(0.90)\end{array}$ & & $\mathrm{x}$ & $\mathrm{x}$ & $\mathrm{x}$ & & \\
\hline$\beta_{\text {(MiZA) }}$ & & & $\begin{array}{l}0.32^{*} \\
(0.43)\end{array}$ & $\mathrm{x}$ & $\begin{array}{l}0.37^{*} \\
(0.54)\end{array}$ & & & & $\mathrm{x}$ & $\begin{array}{l}0.51^{\text {**** }} \\
(0.85)\end{array}$ \\
\hline$\beta_{(\mathrm{MeZA})}$ & & $\begin{array}{l}0.70^{*} \\
(0.56)\end{array}$ & & & $\mathrm{x}$ & $\begin{array}{l}0.66^{* *} \\
(0.54)\end{array}$ & & & $\begin{array}{l}0.92^{*} \\
(0.57)\end{array}$ & $\mathrm{X}$ \\
\hline
\end{tabular}

MeZA data were compared to both surface and $20 \mathrm{~m}$ variables due to the vertical hauling

*None of the selected variables explained the variations. 
Phytoplankton Photosynthetic Efficiency

The photosynthetic efficiencies of the picoand nanoplankton were higher than that of microplankton at the surface $(\mathrm{K}-\mathrm{W}: \mathrm{p}<0.001)$. Near the bottom no differences between size classes were observed $(\mathrm{p}=0.07)$ (Table 1 and Figs $2 \mathrm{c}, \mathrm{d})$. The photic layer depth, estimated from irradiance profiles, varied from 2.0 to $6.0 \mathrm{~m}$ deep during the whole study period. Light intensities at the surface layer varied from 111-586 $\mu \mathrm{E} \mathrm{m}^{-2} \mathrm{~s}^{-1}$ during daylight (08:00 AM to 05:00 PM) while near the bottom light intensities were similar to those at the surface during the night (08:00 PM to 05:00 AM): lower than $0.1 \mu \mathrm{E} \mathrm{m}^{-2} \mathrm{~s}^{-1}$.

\section{Phytoplankton Composition}

The autotrophic nanoplankton community at the surface was mainly composed of the Bacillariophyta Minutocellus sp. (42\%), a filamentous Cyanobacteria Oscillatoriales species (35\%) and the Chlorophyta Tetraselmis gracile (20\%). Near the bottom, Minutocellus sp. (64\%) and the Oscillatoriales species (27\%) were the main components of the autotrophic nanoplankton community.

The autotrophic microplankton community at the surface was mainly composed of Euglenophyta (58\%), with Eutreptia lanowii and Eutreptiella marina the most abundant species, and the Ciliophora $c f$. Myrionecta sp. (29\%). Near the bottom, $c f$. Myrionecta sp. (33\%), Euglenophyta (26\%), with E. lanowii and E. marina as dominant species, and the Bacillariophyta Asterionelopsis sp. (10\%) composed the autotrophic microplankton community.

In both layers, nanoplankton abundance was two orders of magnitude higher than that of microplankton $(p<0.001)$.

Heterotrophic Nanoplankton Abundance and Composition

The heterotrophic nanoplankton compartment was represented by a single species, Protoperidinium cf. bipes, which occurred only at two sampling stations at the surface with 0.02 and $0.14 \times 10^{6}$ ind $\mathrm{L}^{-1}$, respectively.

\section{Microzooplankton Abundance and Composition}

The microzooplankton community at the surface was composed of Ciliophora (Tintinnida: $26 \%$ and aloricate Oligotrichida: 21\%), and one Dinophyta species (Protoperidinium sp.: 24\%). Near the bottom, the aloricate ciliates predominated (Strombidiida: $25 \%$ and other Oligotrichia species: $26 \%$ ), followed by
Tintinnida: 29\% (Table 1 and Figs 3a,b). The multiple regression models showed that the variation in microzooplankton abundance (MiZA) at the surface $\left(\mathrm{R}^{2}=0.93\right)$ was directly dependent on temperature $(\beta=$ $0.42)$ and $\mathrm{PB}_{\text {pico }}(\beta=1.02)$ and inversely dependent on $\mathrm{PB}_{\text {nano }}(\beta=-0.36)$ and $\mathrm{PB}_{\text {micro }}(\beta=-0.38)$, and near the bottom $\left(\mathrm{R}^{2}=0.50\right)$ it was directly dependent on MeZA $(\beta=0.92)($ Table 2$)$.

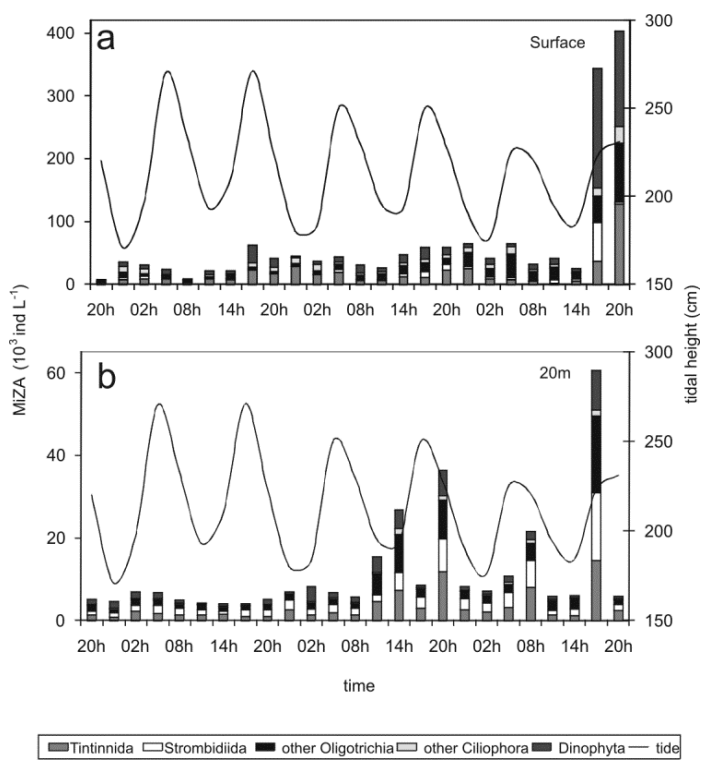

Fig. 3. Abundance of the microzooplankton dominant groups at the surface (a) and $20 \mathrm{~m}$ (b). Lines indicate tidal height.

\section{Mesozooplankton Abundance and Composition}

The mesozooplankton community was mainly composed of Copepoda (78\%) with Acartia tonsa (Dana, 1849) (40\%) and Paracalanus parvus (Claus, 1863) (20\%) as the dominant species. Mysidacea and Appendicularia represented, respectively, $12 \%$ and $5 \%$ of the total mesozooplankton community. The mesozooplankton abundance (MeZA) increased during the study period, mainly due to the increase in A. tonsa abundances, although an increase in the abundances of other copepod species (e.g. P. parvus and Temora turbinata (Dana, 1849)) and mysidaceans was also observed (Fig. 4). The multiple regression models showed that the variation in MeZA throughout the water column was directly dependent on $\mathrm{N}_{-} \mathrm{NH}_{4}(\beta=$ $0.50)$, temperature $(\beta=0.47)$ and MiZA $(\beta=0.37)$ data observed at the surface $\left(\mathrm{R}^{2}=0.73\right)$, and directly dependent on MiZA $(\beta=0.51)$ and inversely dependent on DOC $(\beta=-0.23)$ and temperature $(\beta=$ -0.35) data observed near the bottom $\left(\mathrm{R}^{2}=0.93\right)$ (Table 2). 


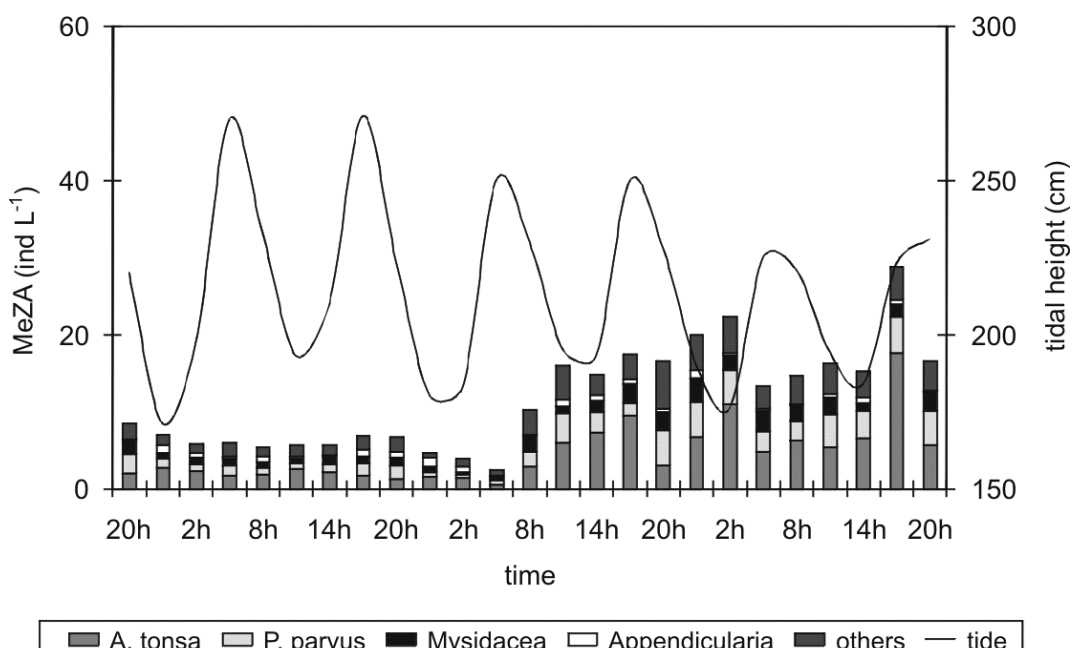

Fig. 4. Abundance of the mesozooplankton dominant species and groups throughout the whole $20 \mathrm{~m}$ water column. Line indicates tidal height.

\section{DisCUSSION}

The biomass and abundance of the plankton compartments assessed in the present study were highly variable and directly correlated to the water temperature. The temperature oscillation at the entrance of Guanabara Bay is directly related to the tidal circulation - the superficial outflow of warmer water from the inner bay and the deep inflow of colder water from the ocean (GUENTHER et al., 2008b), indicating, thus, a strong influence of the hydrological regime on the plankton structure.

Nevertheless, the distinct correlations between specific plankton compartments at each layer suggest that besides the tidal forcing, the plankton structure is also defined by the trophic relationships among these compartments.

\section{Phytoplankton}

The autotrophic compartment was mainly represented, in terms of biomass, by the nano- and microplankton. It was expected that the larger phytoplankton would prevail, as the complex hydrodynamism of Guanabara Bay (i.e., tidal currents and continental runoff) coupled with the intense eutrophication result in large and sporadic nutrient pulses (VALENTIN et al., 1999), favoring the larger cells. Nevertheless, when comparing the photosynthetic efficiencies of the three phytoplankton size classes, the picoplankton rates were similar to (or higher than) those of nano- and microplankton.

The equivalent photosynthetic efficiency of the three size classes and the lower picoplankton biomass indicate that the smaller cells are synthesizing biomass as much as the larger ones, but it is possibly being preferentially lost from the system. The phytoplankton export can be due to vertical transport (sinking), lateral transport (advection) or grazing (e.g. LEGENDRE; RIVKIN, 2002; STUKEL et al., 2011; ADJOU et al., 2012; TORTAJADA et al., 2012). Small cells are able to remain in suspension longer due to their high surface/volume ratio (GUENTHER; BOZELLI, 2004), and lateral transport is not size selective. Therefore, it is most probable that the picoplankton is being removed from the system through grazing.

Near the bottom, both pico- and nanoplankton presented lower photosynthetic efficiencies than at the surface, which is possibly due to the low light intensities at that depth. Micro-sized cells, however, present higher maximum quantum efficiencies $\left(\varphi_{\mathrm{m}}\right)$ than smaller ones (HARRIS et al., 1983) which may explain their similar photosynthetic efficiencies at both layers. Moreover, the autotrophic microplankton community at both layers was mainly composed of autotrophic ciliates ( $c f$. Myrionecta) and flagellates (euglenophytes), which present higher mobility than other micro-sized cells such as diatoms. This mobility allows those cells to experience simultaneously optimum light and nutrient conditions (REYNOLDS, 2006) and is another possible reason why this compartment presented similar $\mathrm{P}^{\mathrm{B}}$ throughout the water column.

The lower microplankton biomass near the bottom regarding the equivalent $\mathrm{P}^{\mathrm{B}}$ as at the surface suggests that part of it is also being removed from this site, through either advection (ocean inflow) or grazing. 
Microzooplankton

The microzooplankton community at the entrance of Guanabara Bay was composed of omnivorous groups (Ciliophora and Dinophyta), able to consume a wide size range of both auto- and heterotrophic prey, from pico- to micro-sized ones (SHERR, E. B.; SHERR, B. F., 1987; STROM, 2002). The direct correlation between the microzooplankton and the autotrophic picoplankton in the surface layer indicates a possible trophic link between these two compartments. The heterotrophic nanoplankton (HN) usually acts as a link between the pico- and the microzooplankton (e.g. STROM, 2000; VARGAS; MARTINEZ, 2009; TARBE et al., 2011). In the present study, the only species of $\mathrm{HN}$, Protoperidinium cf. bipes, was only found in two sampling periods in the surface layer. The reason why this compartment was virtually absent from our samples remains uncertain. If there was a methodological problem, the possible under sampled HN community could be acting as a link between the autotrophic picoplankton and the microzooplankton, as observed in a previous survey at nearby sites in Guanabara Bay (GOMES et al., 2007). On the other hand, if the $\mathrm{HN}$ community at the entrance of Guanabara bay is actually absent, the microzooplankton may be grazing directly upon the autotrophic picoplankton, as already pointed out in previous studies worldwide (e.g. SHERR, E.B.; SHERR, B.F., 2002; CALBET; LANDRY, 2004; LIU et al., 2005).

\section{Mesozooplankton}

The mesozooplankton community was mainly composed of calanoid copepods, with Acartia tonsa and Paracalanus parvus as dominant species. The increase in its abundance during the study is possibly due to the establishment of the gravitational circulation at the beginning of the neap tide period (GUENTHER et al., 2008b), increasing the runoff from the inner bay at the surface and the oceanic currents near the bottom. Acartia tonsa, the species with the greatest increase in abundance at the beginning of the neap tide ( $36 \mathrm{~h}$ after the beginning of the study), is most frequent in brackish waters (BOLTOVSKOY, 1999) and is one of the few mesozooplankton species that persist in high densities in the inner parts of Guanabara Bay (GOMES et. al, 2004). Moreover, the observed increase in the abundances of the neritic species (i.e., $P$. parvus and mysidaceans) in this period indicates the higher oceanic contribution to the bay at the bottom layer.

As the mesozooplankton was sampled for the whole water column, it is not possible to define their distribution in those two layers or to establish whether the lateral transport due to tidal currents affects their nictemeral vertical migration. However, another study performed in the same area during stratified conditions (neap tide) showed that $A$. tonsa and $P$. parvus present different migratory behaviors: while $A$. tonsa shows a classical vertical migration pattern, being above the thermocline at night and below it during the day, $P$. parvus is limited to the bottom layer (GOMES et al., 2004). Mysidaceans are also usually associated with benthic substrates (BOLTOVSKOY, 1999). It is, therefore, possible that A. tonsa dominates the low saline surface waters while the other components such as $P$. parvus and mysidaceans are restricted to the more saline bottom waters.

The feeding behaviour of $A$. tonsa is usually not selective, including diatoms, dinoflagellates (both auto- and heterotrophic) and ciliates as well as detrital particles (KLEPPEL; HAZZARD, 2000; GASPARINI et al., 2000; ROMAN et al., 2006). In the present study, the direct correlations observed at the surface layer between the mesozooplankton and both autotrophic nanoplankton (diatoms, filamentous cianobacteria and chlorophytes) and microzooplankton (ciliates and dinoflagellates) suggest a possible trophic link between the mesozooplankton (mainly represented by $A$. tonsa in this layer) and those two compartments.

Near the bottom, both autotrophic microplankton and microzooplankton were directly correlated to the mesozooplankton dynamics, suggesting an omnivorous behavior for the bottom layer mesozooplankton species $(P$. parvus and Mysidaceans). Mysidaceans are typically detritivorous, feeding on benthic particles (BOLTOVSKOY, 1999) while $P$. parvus is mostly herbivorous (GIESECKE; GONZALEZ, 2004). It is thus possible that the autotrophic microplankton community in the bottom layer (comprised by the symbiont ciliate $c f$. Myrionecta sp., the euglenophytes - Eutreptia lanowii and Eutreptiella marina and the diatom Asterionelopsis sp.) is supporting the P. parvus populations.

Microzooplankton prey, both dinoflagellates and ciliates, has been shown to be preferred over diatoms by many copepod species (e.g. CALBET; SAIZ, 2005; JONES; FLYNN, 2005; GIFFORD et al., 2007; CAMPBELL et al., 2009; LIU et al., 2010; CHEN; LIU, 2011; SAIZ; CALBET, 2011). The direct correlations between the microzooplankton and the mesozooplankton observed near the bottom at the entrance of Guanabara bay, also suggest a trophic link between these two compartments. The microzooplankton, comprised mainly by aloricate ciliates in this layer, could be supporting the $P$. parvus population, if it is capable of grazing on both auto- and heterotrophic microplankton, and the $A$. tonsa 
population, which migrates from the surface layer to feed on the bottom layer. Therefore both auto- and heterotrophic microplankton seem to be supporting the mesozooplankton community at this layer.

\section{Trophic Interactions}

The intense hydrodynamics at the entrance of Guanabara Bay, leading to the separation of the water column into two distinct layers, result in the establishment of two distinct trophic interactions within the plankton (Fig. 5). At the surface the plankton food web is based on the smaller phytoplankton: nano- and picoplankton, this last being channeled through the microzooplankton to support the mesozooplankton community. Near the bottom the autotrophic microplankton seems to be the main carbon source for the plankton trophic web, being directly grazed by the mesozooplankton. The microzooplankton at this layer, which is also supporting the mesozooplankton community, was not correlated with any phytoplankton size class, and could be feeding on the heterotrophic nanoplankton (not significantly observed in the present study) or directly on the bacterial colonized detrital particles. The entrance of Guanabara Bay presents thus a combination of both classical and microbial trophic pathways: a multivorous food web (LEGENDRE; RASSOULZADEGAN, 1995), also observed in other unsteady systems such as those influenced by upwelling events (VARGAS et al., 2007; GUENTHER et al., 2008a).

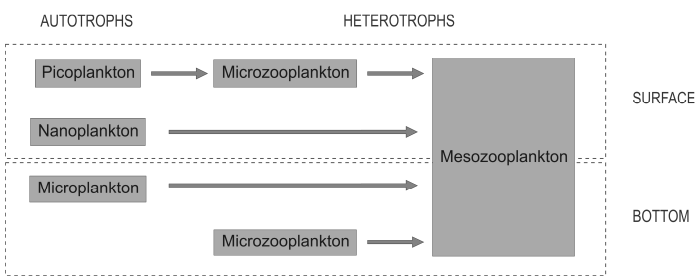

Fig. 5. Proposed plankton trophic structure at the entrance of Guanabara Bay at both surface and bottom layers.

The carbon fluxes within this area will thus depend on the amount produced and transferred by each proposed trophic link at each layer. In longer food chains (e.g., at the surface: autotrophic picoplankton - heterotrophic nanoplankton microzooplankton - mesozooplankton) there is a higher carbon loss through respiration (i.e., carbon regeneration). Conversely, in shorter food chains (e.g., near the bottom: autotrophic microplankton mesozooplankton), a greater amount of carbon is available for export (e.g. LEGENDRE; LE FEVRE, 1989; VARGAS et al., 2007;STUKEL et al., 2011). Since the bottom layer is moving towards the inner bay while the surface layer is flowing outwards, at least during neap tide periods, if the carbon balance at each of these layers is positive (i.e., export higher than regeneration), it will result in export in both directions (LEGENDRE; RIVKIN, 2002). Alternatively, if the carbon balance is negative (i.e., regeneration higher than export) it will result in an inorganic carbon $\left(\mathrm{CO}_{2}\right)$ vertical flux, i.e., from the bottom to the surface layer or from this to the atmosphere (DUCKLOW et al., 2001).

These proposed trophic links are still estimates based on the correlations between the plankton compartments and should be confirmed as well as weighted in terms of the amount of carbon transferred in in situ grazing experiments (e.g. SANCHÉZ et al., 2011; VARGAS et al., 2012). Nevertheless, the present study reveals the complexity of the plankton structure in systems with high hydrological variability and represents an important starting point for the modelling of the carbon fluxes in this and other similar tropical systems.

\section{ACKNOWLEDGEMENTS}

The authors thank Petrobras, the IEAPM technicians, and the $\mathrm{R} / \mathrm{V}$ Astrogaroupa crew for laboratory and field support, the Laboratório de Hidrobiologia (IB/UFRJ) for the chl $a$ analyses, and one anonymous referee for important suggestions on the manuscript. Field work and analyses were supported by grants from the National Research Council (CNPq - 3306.188/2004-0) and the Rio de Janeiro State Research Foundation (FAPERJ - E26/151.949/2004). M. G. was supported by a doctoral fellowship from CNPq (141873/2003-5), I. L. and G. M. were respectively supported by masters' fellowships from CAPES and CNPq.

\section{REFERENCES}

ADJOU, M; BENDTSEN, J; RICHARDSON, K. Modeling the influence from ocean transport, mixing and grazing on phytoplankton diversity. Ecol. Model., v. 225, p. 19$27,2012$.

BOLTOVSKOY, D. South Atlantic Zooplankton. Leiden: Backhuys Publishers, 1999. 1706 p.

CALBET, A.; LANDRY, M. R. Phytoplankton growth, microzooplankton grazing, and carbon cycling in marine systems. Limnol. Oceanogr., v. 49, p. 51-57, 2004.

CALBET, A.; SAIZ, E. The ciliate-copepod link in marine ecosystems. Aquat. Microb. Ecol., v. 38, p. 157-167, 2005.

CAMPBELL, R. G.; SHERR, E. B.; ASHJIAN, C. J.; PLOURDE, S.; SHERR, B. F.; HILL, V.; STOCKWELL, A. Mesozooplankton prey preference and grazing impact in the western Arctic Ocean. DeepSeaRes. II, v. 56, p. 1274-1289, 2009. 
CHEN, M.; LIU, H. Experimental simulation of trophic interactions among omnivorous copepods, heterotrophic dinoflagellates and diatoms. J. Exp. Mar. Biol. Ecol., v. 403, p. 65-74, 2011

DUCKLOW, H. W; STEINBERG, D. K.; BUESSELER, K. Upper ocean carbon export and the biological pump. Oceanography, v. 14, p.50-58, 2001.

DYER, K. R. Estuaries: a physical introduction. West Sussex: John Wiley and Sons, 1997. $195 \mathrm{p}$.

GASPARINI, S.; DARO, M. H.; ANTAJAN, E.; TACKX, M.; ROUSSEAU, V.; PARENT, J. Y.; LANCELOT, C. Mesozooplankton grazing during the Phaeocystis globosa bloom in the Southern Bight of the North Sea. J. Sea Res., v. 43, p. 345-356, 2000.

GIESECKE, R.; GONZALEZ, H. E. Mandible characteristics and allometric relations in copepods: reliable method to estimate prey size and composition from mandible occurrence in predator guts. Rev. Chil. Hist. Nat. , v. 77, p. 607-616, 2004.

GIFFORD, S. M.; ROLLWAGEN-BOLLENS, G.; BOLLENS, S. M. Mesozooplankton omnivory in the upper San Francisco Estuary. Mar. Ecol. Prog. Ser., v. 348, p. 33-46, 2007.

GOMES, C.; MARAZZO, A; VALENTIN, J. L. 2004. The vertical migration behaviour of two calanoid copepods, Acartia tonsa Dana, 1849 and Paracalanus parvus (Claus, 1863) in a stratified tropical bay in Brazil. Crustaceana, v. 77, p. 941-954, 2004

GOMES, E. A. T.; SANTOS, V. S.; TENENBAUM, D. R.; VILLAC, M. C. Protozooplankton characterization of two contrasting sites in a tropical coastal ecosystem (Guanabara Bay, RJ). Braz. J. Oceanogr., v. 55, p 2938, 2007.

GRIFFTHS, F. B.; FLEMINGER, A.; KIMOR, B.; VANUCCI, M. Shipboard and curating techiniques. In: UNESCO (Ed.). Zooplankton fixation and preservation - monographs on oceanographics methodology. Paris: UNESCO Regional Office, 1976. p. 17-19.

GUENTHER, M.; BOZELLI, R. Factors influencing algaeclay aggregation. Hydrobiologia 523: 217-223, 2004.

GUENTHER, M; GONZALEZ-RODRIGUEZ, E.; CARVALHO, W. F; REZENDE, C. E.; MUGRABE, G.; VALENTIN, J. L. Plankton trophic structure and particulate organic carbon production during a coastal downwelling-upwelling cycle. Mar. Ecol. Prog. Ser., v. 363, p. 109-119, 2008a.

GUENTHER, M.; PARANHOS, R.; REZENDE, C. E.; GONZALEZ-RODRIGUEZ, E.; VALENTIN, J. L. Dynamics of bacterial carbon metabolism at the entrance of a tropical eutrophic bay influenced by tidal oscillation. Aquat. Microb. Ecol., v. 50, p. 123-133, 2008b.

HARRIS, G. P.; PICCININ, B. B.; VANRYN, J. Physical variability and phytoplankton communities. 5. cell-size, niche diversification and the role of competition. Arch. Hydrobiol., v. 98, p: 215-239, 1983.

JICA. The study on recuperation of the Guanabara bay ecosystem. Tokyo: Japan International Cooperation Agency, 1994. 537 p.

JONES, R. H.; FLYNN, K. J. Nutritional status and diet composition affect the value of diatoms as copepod prey. Science, v. 307, p. 1457-1459, 2005.

KLEPPEL G. S.; HAZZARD, S. E. Diet and egg production of the copepod Acartia tonsa in Florida Bay. II. Role of nutritional environment. Mar. Biol., v. 137, p. 111-121, 2000

KÖPPEN, W. Versuch einer Klassifikation der Klimate, vorzugsweise nach ihren Beziehungen zur Pflanzenwelt. Geogr. Zeitsch., v. 6, p. 593-611; 657-679, 1900.

LEGENDRE, L; Le FEVRE, J. Hydrodynamical singularities as controls of recycled versus export production in oceans. In: BERGER, W. H.; SMETACECK, V. S.; WEFER, G. (Ed.). Productivity of the ocean: present and past. Dahlem Konferenzen. Chichester: John Wiley, 1989. p. 49-63.

LEGENDRE, L.; LE FEVRE, J. Microbial food webs and the export of biogenic carbon in oceans. Aquat. Microb. Ecol., v. 9, p. 69-77, 1995.

LEGENDRE, L.; RASSOULZADEGAN, F. Plankton and nutrient dynamics in Marine waters. Ophelia, v. 41, p. 153-172, 1995

LEGENDRE, L.; RASSOULZADEGAN, F. Food-web mediated export of biogenic carbon in oceans: hydrodynamic control. Mar. Ecol. Prog. Ser., v. 145, p. 179-193, 1996.

LEGENDRE, L.; RIVKIN, R. B. Fluxes of carbon in the upper ocean: regulation by food-web control nodes. Mar. Ecol. Prog. Ser., v. 242, p. 95-109, 2002.

LIU, H.; DAGG, M. J.; STROM, S. Grazing by the calanoid copepod Neocalanus cristatus on the microbial food web in the coastal Gulf of Alaska. J. Plankton Res., v. 27, p. 647-662, 2005.

LIU, H.; CHEN, M.; SUZUKI, K.; WONG, C. K.; CHEN, B. Mesozooplankton selective feeding in subtropical coastal waters revealed by HPLC pigment analysis. Mar. Ecol. Prog. Ser., v. 407, p. 111-123, 2010.

MAYR, L. M.; TENEMBAUM, D. R.; VILLAC, M. C.; PARANHOS, R.; NOGUEIRA, C. R.; BONECKER, S. L. C.; BONECKER, A. C. T. Hydrobiological characterization of Guanabara Bay. In MAGOON, O.; NEVES C. (Ed.). Coastlines of Brazil. New York: American Society of Civil Engineers, 1989. p. 124-138.

MIRANDA, L. B. de; CASTRO, B. M. de; KJERFVE, B. Princípios de oceanografia física dos estuários. São Paulo: EDUSP, 2002. 414 p.

PARSONS, T.; MAITA, Y.; LALLI, C. A manual of chemical and biological methods for seawater analysis. Oxford: Pergamon Press, 1984. 184 p.

REYNOLDS, C. S. Ecology of phytoplankton: ecology, biodiversity and conservation. Cambridge: Cambridge University Press, 2006. 535 p.

RIVKIN, R. B.; LEGENDRE, L. Roles of food web and heterotrophic microbial processes in upper ocean biogeochemistry: global patterns and processes. Ecol. Res., v. 17, p. 151-159, 2002.

ROMAN, M. R.; REAUGH M. L.; ZHANG, X. S. Ingestion of the dinoflagellate, Pfiesteria piscicida, by the calanoid copepod, Acartia tonsa. Harmful Algae, v. 5, p. 435441, 2006.

SAIZ, E.; CALBET, A. 2011. Copepod feeding in the ocean: scaling patterns, composition of their diet and the bias of estimates due to microzooplankton grazing during incubations. Hydrobiologia, v. 666, p. 181-196, 2011.

SANCHEZ, N.; GONZALEZ, H. E.; IRIARTE, J. L. Trophic interactions of pelagic crustaceans in Comau Fjord (Chile): their role in the food web structure. J. Plankton Res., v. 33, p. 1212-1229, 2011. 
SANTOS, V. S.; VILLAC, M. C.; TENENBAUM, D. R PARANHOS, R. Auto- and heterotrophic nanoplankton and filamentous bacteria of Guanabara bay (RJ, Brazil): estimates of cell/filament numbers versus carbon content. Braz. J. Oceanogr., v. 55, p. 133-143, 2007.

SCHWAMBORN, R; BONECKER, S. L. C; GALVÃO, I. B.; SILVA, T. A.; NEUMANN-LEITÃO, S. Mesozooplankton grazing under conditions of extreme eutrophication in Guanabara Bay, Brazil. J. Plankton Res., v. 26, p. 983-992, 2004.

SHERR, E. B.; SHERR, B. F. High-rates of consumption of bacteria by pelagic ciliates. Nature, v. 325 , p. 710-711, 1987.

SHERR, E. B.; SHERR, B. F. Preservation and storage of samples for enumeration of heterotrophic protists. In KEMP, P. F.; SHERR, B. F.; SHERR, E. B.; COLE, J. J. (Ed.). Handbook of methods in aquatic microbial ecology. Boca Raton: Lewis Publishers, 1993. p. $207-$ 212.

SHERR, E.B.; SHERR, B. F. Significance of predation by protists in aquatic microbial food webs. Anton. Leeuw. Int. J. G., v. 81, p. 293-308, 2002.

STEEMANN-NIELSEN, E. 1952. The use of radio-active carbon $\left({ }^{14} \mathrm{C}\right)$ for measuring organic production in the sea. J. Cons. Int. Explor. Mer, v. 18, p. 117-140, 1952.

STROM, S. L. Bacterivory: interactions between bacteria and their grazers. In KIRCHMAN, D. L. (Ed.). Microbial Ecology of the oceans. New York: Wiley-Liss, 2000. p. 351-386.

STROM, S. Novel interactions between phytoplankton and microzooplankton: their influence on the coupling between growth and grazing rates in the sea. Hydrobiologia, v. 480, p. 41-54, 2002

STUKEL, M. R.; LANDRY, M. R.; BENITEZ-NELSON, C. R.; GOERICKE, R. Trophic cycling and carbon export relationships in the California Current Ecosystem. Limnol. Oceanogr., v 56, p. 1866-1878, 2011.

TARBE, A.; UNREIN, F.; STENUITE, S; PIRLOT, S; SARMENTO, H; SINYINZA, D; DESCY. J. P. Protist herbivory: a key pathway in the pelagic food web of Lake Tanganyika. Microb. Ecol., v. 62, p. 314-323, 2011.

TIAN, R. C.; VEZINA, A. F.; LEGENDRE, L.; INGRAM, R. G.; KLEIN, B.; PACKARD, T.; ROY, S.; SAVENKOFF, C.; SILVERBERG, N.; THERRIAULT, J. C.; TREMBLAY, J. E. Effects of pelagic food-web interactions and nutrient remineralization on the biogeochemical cycling of carbon: a modeling approach. Deep-Sea Res II, v. 47, p. 637-662, 2000.
TORTAJADA, S.; NIQUIL, N.; BLANCHET, H.; GRAMI, B.; MONTANIÉ, H; DAVID, V; GLÉ, C; SAINTBÉAT, B.; A. JOHNSON, G. A.; MARQUIS, E.; DEL AMO, Y.; DUBOIS, S.; VINCENT, D.; DUPUY, C.; JUDE, F.; HARTMANN, H. J.; SAUTOUR, B. 2012. Network analysis of the planktonic food web during the spring bloom in a semi enclosed lagoon (Arcachon, SW France). Acta Oecol., v. 40, p. 40-50, 2012.

UTERMÖHL, H. Zur Vervollkomnung der quantitativen Phytoplankton-Methodik. Mitt. Int. Verein. theor. angew. Limnol., v. 9, p. 1-38, 1958.

VALENTIN, J. L.; TENENBAUM, D. R.; BONECKER, A. C. T; BONECKER, S. L. C.; NOGUEIRA, C. R.; PARANHOS, R.; VILLAC, M. C. Caractéristiques hydrobiologiques de la baie de Guanabara (Rio de Janeiro, Brésil). J. Rech. Ocean., v. 24, p. 33-41, 1999.

VARGAS, C. A.; MARTINEZ, R. A.; CUEVAS, L. A.; PAVEZ, M. A.; CARTES, C.; GONZALEZ, H. E.; ESCRIBANO, R; DANERI, G. The relative importance of microbial and classical food webs in a highly productive coastal upwelling area. Limnol. Oceanogr., v. 52, p. 1495-1510, 2007.

VARGAS, C. A.; MARTÍNEZ, R. A. Grazing impact of natural populations of ciliates and dinoflagellates in a river-influenced continental shelf. Aquat. Microb. Ecol.,v. 56, p. 93-108, 2009.

VARGAS, C. A.; CONTRERAS, P. Y.; IRIARTE, J. L. 2012. Relative importance of phototrophic, heterotrophic, and mixotrophic nanoflagellates in the microbial food web of a river-influenced coastal upwelling area. Aquat. Microb. Ecol., v. 65, p. 233-248, 2012.

VILLAC, M. C.; TENENBAUM, D. R. The phytoplankton of Guanabara Bay, Brazil. I. Historical account of its biodiversity. Biota Neotrop., v. 10, p. 271-293, 2010.

WANDENESS, A. P.; MATTOS, M. A. R; NOGUEIRA, C. S. R. Copepoda (Crustacea) of Guanabara Bay, RJ. I. Specific composition. Arq. Biol. Tecnol., v. 40, p. 377381, 1997.

(Manuscript received 28 March 2011; revised 29 March 2011; accepted 12 November 2012) 